\title{
Searching for stillness in the flux of the electric world: Vorticular media theory from Wyndham Lewis to Marshall McLuhan
}

Thomas Sutherland

Early on in his career as a media theorist (having started out teaching English literature), between the relatively straightforward cultural criticism of The Mechanical Bride and the more idiosyncratic historical analysis of The Gutenberg Galaxy, the latter of which would confirm his status as one the leading public intellectuals of the twentieth century, Marshall McLuhan produced the first edition of Counterblast, an odd pamphlet that is typically overlooked in considerations of his oeuvre. Both tonally and stylistically, Counterblast is a deliberate mimicry and homage to Blast, the modernist literary magazine created by the English painter and writer Wyndham Lewis. In this article, I examine more closely the intersection between Lewis and McLuhan, focusing specifically upon the question of time and its relationship to the artist, arguing that both of these thinkers offer a prescient reflection upon the disorienting temporal conditions imposed upon us in the wake of industrialization (and now post-industrial digital culture) - a time when, more than ever, 'change is itself the only constant' (McLuhan 1987: 254).

Blast, which only lasted two issues (published in 1914 and 1915, respectively), trumpets the arrival of the short-lived Vorticist art movement, which heightened the geometric abstraction of Cubism (spurning all direct representation and mimesis) whilst combining it with the industrially-inspired aesthetics and penchant for bombastic manifestos of the Italian Futurists. Rejecting the Futurists' romanticized vision of industrial society, and their concomitant celebration of the 'advanced', 'progressive' features of modern life, the Vorticists had no interest in a one-sided valorization of speed and motion, instead seeking to heighten the tension between the formalism (and implicit stasis) of Cubism and the dynamism of Futurism, bringing to the foreground the stillness that lies at the core of all movement (hence the founding metaphor of the vortex, which spirals around a fixed centre). 'Instead of multiple images, and blurred, merging forms', writes William C. Wees (1972: 115), in his comprehensive survey of the Vorticist movement, their 'machine aesthetic produced static, rigidly geometrical, and nearly or completely abstract designs'.

The Vorticist critique of the Futurists' fanatical devotion to the accelerating temporalities of modernity - the latter championing that which FT Marinetti (2006: 13) described as 'a new beauty: the beauty of speed' - would find its most thorough and biting expression in Lewis' Time and Western Man. It is not merely Marinetti and his associates, however, who become subjects of condemnation here, for Lewis (1957: 11) views the Futurist cause, and its cult of time, as of a piece with the fashionable philosophies of becoming propounded by figures such as Henri Bergson and A.N. Whitehead, in each case, seeing merely confirmation of the nihilistic impulses of industrial capitalism, a 'glorification of the life-of-themoment, with no reference beyond itself and no absolute or universal value'. He denounces these thinkers' obsession with the immediacy of affective temporal experience, considering this covert antiintellectualism as auguring a return to the magic and religious superstition of primitive humankind. In the words of McLuhan (2011d: 5), whose work is pronouncedly indebted to the art and literature of early-twentieth century modernism, Lewis is 'a one-man army corps opposed to these forces which seek to use art, science, and philosophy in order to reduce our world to the nocturnal womb from which they suppose it to have been born'. Although they may seem an unlikely pairing, what both of these thinkers share is a commitment to the utilization of art as a means of 'delivering us from the time mechanism of existence' (McLuhan 2011d: 6), seeking out those moments of quietude and even stasis that would be 
Thomas Sutherland (2018) 'Searching for stillness in the flux of the electric world: Vorticular media theory from Wyndham Lewis to Marshall McLuhan', Explorations in Media Ecology. 17 (1): 7-22.

https://doi.org/10.1386/eme.17.1.7_1

otherwise be lost within the fevered acceleration of everyday life that accompanied the processes of modernization.

Metaphor operates within McLuhan's work, argues Jana Mangold (2014: 18), as 'a particular epistemological wager in the study of the new scientific object called media', and the image of the vortex specifically, which is introduced by Ezra Pound in the first issue of Blast, corresponds neatly with one of McLuhan's favourite literary metaphors - Poe's sailor who survived his descent into the maelstrom symbolizing the irreconcilable tension between chaos and order, movement and stasis within our contemporary media landscape. The attractiveness of the modernists to McLuhan (1987: 220), somewhat strangely, is not their invocation of the radically new, but their ability to retrieve that which had been gradually lost in literature culture, their aesthetic discoveries serving 'to recreate in contemporary consciousness an awareness of the potencies of language such as the Western world has not experienced in 1800 years'. In light of contemporary conditions of socio-technical acceleration, I wish to suggest that the Vorticist approach to media, as advocated by McLuhan, provides a valuable, albeit limited, corrective to the ontological privileging of time (and with it change, difference, flux, etc.) within contemporary media theory, encouraging us to seek out those aspects of experience that remain sturdy within the seemingly unstoppable march of technological development.

\section{The privileging of space over time}

In order to understand the influence of Lewis' aesthetic principles upon McLuhan's media theory, we must first look at the way in which the former sought to distance himself from both contemporary philosophers and art movements, deriding the fetishization of time. Lewis' opprobrium, especially during the short life of the Vorticist movement proper, was directed chiefly at Italian Futurism, which for all of its questionable political adherences would have a sizeable impact upon Western art and culture in the early twentieth century. Futurism is built upon an aesthetics of movement, technology, and violence. Its inspiration, writes Paul Virilio (2006: 84), 'comes from a single art - that of war and its essence, speed'. The logistics of war, and the increasingly mechanized conflict that would find its logical end in the horrific brutality of World War I, provided much of the relentless energy and dynamism from which the Futurists' enthusiastically drew in their art. Marinetti (2006: 14) expresses this point quite clearly himself, declaring his 'wish to glorify war - the only cleanser of the world - militarism, patriotism, the destructive act of the libertarian, beautiful ideas worth dying for, and scorn for women'.

Putting aside the noxious misogyny typical of the avant-garde art community at the time, what is crucial for us is the way in which Marinetti views art as a means of not only facilitating, but actually precipitating and expediting the dramatic social transformations wrought by industrialization. Futurism sought a radical break from the past, from the tradition in which they saw Italy as mired, embracing the affective thrill of technicized mobility against all staid intellectualisms. Whilst Lewis 'found Marinetti interesting, amusing, and useful to the avant-garde cause' (Wees 1972: 100), he quickly tired of his singleminded romanticization of the celerity of mechanized culture. The Vorticists, by contrast, emphasized the importance of dispassionate intellection, seeking out the immobility and rigour that the Futurists saw as hindering the forward-motion of social and technological progress. 'The Vorticist is at his maximum point of energy when stillest', writes Lewis (1914b: 148) in his manifesto for this emergent movement, for he 'is not the Slave of Commotion, but it's [sic] Master'.

Vorticism did not see industrial society and its various technological innovations as a marvel; rather, it saw them as an everyday fact (especially in England), undue excitement about which would just distract from the cold, precise abstraction sought. Lewis and the Vorticists were searching, as Sheila Watson (2003: 52) writes, for 'a new visual language which could compete with the "form language" of the machine'. It was not that they at all distanced themselves from the aesthetic appeal of mechanization - 
Thomas Sutherland (2018) 'Searching for stillness in the flux of the electric world: Vorticular media theory from Wyndham Lewis to Marshall McLuhan', Explorations in Media Ecology. 17 (1): 7-22.

https://doi.org/10.1386/eme.17.1.7_1

the formal, abstract qualities of the machine are probably more evident in the work of the Vorticists than any art movement prior - but that they saw Futurism, with its fanatical devotion to speed, as blurring and obscuring precisely those features of the machine that were of greatest importance (in particular, its explosive, inhuman powers of destruction). 'Lewis saw in Futurism not a counter-movement, but a surrender' (Watson 2003: 92). In their unflinching romanticism and their emphasis upon affective appeal, the Futurists ended up humanizing the machine, assimilating it into an anachronistic conceptual framework. By focusing so heavily on time, striving to seize (rather than evade or subvert) the persistent flux of experience, they failed to truly capture the spirit of the machine age.

In Time and Western Man, published several years after the formal dissolution of the Vorticists, Lewis elaborates upon this critique, articulating a loose metaphysical and aesthetic theory of realism that privileges space over time:

[a]s a realist, in the most sensible acceptance of the word, and as of course we all are, whatever we are merely called, what is the strongest impression you receive from the external world, or nature? Certainly stability, I as a realist, should say: decidedly not one of change. For change you have to look, to wait for, you have to detect it (1957: 205).

He associates this preoccupation with change not only with the Futurists, but also with philosophers such as Whitehead and Bergson, who assert the ontological and psychological primacy of time, and the concomitantly illusory nature of all that appears immutable (in a reversal of the classical equivalence of truth with eternal perdurance). The Futurists hoped to achieve in art, it would seem, what these philosophers likewise attempted to fulfil in their own discipline: that which T.E. Hulme (1924: 94) had previously described as 'deification of the flux'; the presentation of a world lacking all certainty in anything other than perpetual change.

Bergson (1946: 131), for example, premises his then-eminent philosophy upon the search for a 'vision of universal becoming' - a primordial mobility, equated with the inherently free activity of the human individual, of which all appearance of stability is a mere structuration and regulation. Philosophy, in Bergson's (1946: 131) conception, actually marks a significant improvement over art, offering us a vision of thought and the world wherein ' $r$ ] eality no longer appears ... in the static state, in its manner of being; it affirms itself dynamically, in the continuity and variability of its tendency'. But whereas he views such an approach as providing access to an intuition of time unsullied by the mechanistic logic of homogeneous segmentation (which parcels time out upon a linear axis), Lewis (1957: 174) sees it instead as a philosophical reification of the industrial mentality and the clockwork operation of the machinery upon which it relies: '[f] or locomotion and movement, "organism” in the making, or becoming, not become,' he asks, 'what is that but a machine?'.

The problem here, of course, does not lie in the fact that Bergson relies upon this mechanical figuration within his philosophy - Lewis himself is fascinated by the explosive power of such machinery. The issue, rather, is that Bergson misrepresents the source of his adherence to an ontology of becoming (counterposed against the rigidity of being), ascribing to an internal and organic duration a continuity that is in fact the product of a thoroughly industrial mindset:

[t]he obsession of a mechanical betterment, proceeding without ceasing, is natural to industrial man; the "progress" of the engineer, the rapid changes and improvements of the technique of industry, make it natural for him to regard everything in terms of change and improvement, and to think that he can apply to himself or to other men the methods proper to machinery (Lewis 1957: 121-122). 
Thomas Sutherland (2018) 'Searching for stillness in the flux of the electric world: Vorticular media theory from Wyndham Lewis to Marshall McLuhan', Explorations in Media Ecology. 17 (1): 7-22.

https://doi.org/10.1386/eme.17.1.7_1

The emphasis that Bergson places upon the continuity of this intuition, of living in a moment that can be figured neither as a natural progression from the past, nor as an accurate predictor of a future-to-come, simply replicates the unthinking enthusiasm prized in the modern worker - the individual who places a continued efficiency and productivity (means) above any rational end-goal.

In short, Lewis (1957: 359), who observes that 'all magicians dislike permanence, and are naturally sympathetic towards the flux', views both Bergson and Whitehead as continuing down the same path as the Futurists in reifying the magic and mystification of modern life, promoting an uncritical celebration of dynamism at the expense of any real theoretical reflection upon the values of such a principle. It was a triumph of intuition over intellect, feeling and emotion over rationality and critical distance, demonstrating 'a self indulgent habit of mind or a tendency to shut the eyes to what is unpleasant, in favour of things arbitrarily chosen for their flattering pleasantness' (Lewis 1957: 10). Considering these philosophers' obsession with change as a regression back into primitive superstition, rather than as an indicator of their commitment to social progress (whatever form this might take), Lewis (1957: 205-206) declares that " $\mathrm{i}] \mathrm{f}$ there is one thing more than another that is essential to provide a "sense of reality" our sheer sensation that there is something real there before us - it is the deadness, the stolid thickness and deadness, of nature'. Art, in this context, is not a celebration of change - something that aims 'to provide for the soul vivid, but transient, values' (Whitehead 1925: 202) - but a means of guiding the mind toward those truths that persist amongst the flux of quotidian experience.

There is a philosophical unsophistication to Lewis' critique here that is in equal measures endearing and limiting. Unapologetically polemical, expressing a view of reality (and the means of apprehending it) that is largely derivative of his artistic predilections, it would not be unreasonable to suggest that in arguing that 'it is the abstraction of the materialistic picture of science that puts the movement and the fusion into it', Lewis (1957: 205) simply instigates yet another reversal in primacy of the relationship between space and time, without providing any more substantial justification. Yet there is a certain novelty in the perspective that he puts forward, advocating not only non-representational abstraction, but also disdaining the pleasure and romance that the Futurists saw in the speed and violence of mechanical technology.

\section{Art as counter-environment}

It is Lewis' decided absence of rhapsodic enthusiasm in the face of technological advancement, his derision of other artists' and philosophers' fervour for the new aesthetic values engendered by mass media, and his support for the virtues of Western rationality against these forces of fashionable mysticism, that seems to offer such vivid appeal to McLuhan (2011d: 7), who argues that the former's attacks on both futurists (in the broader sense of the term) and nostalgics alike seeks 'to deliver us from the bondage of primitive religion with its obsession with recurrence, and the way of destruction as the way of rebirth'. McLuhan (2003: 16), who held a personal, albeit fitful correspondence and friendship with Lewis from the 1940s onward, remarks that the latter 'devoted much of his energy to the study and delineation of the Western drift back into the "sacred" auditory space of primitive and irrational man' - that is, he recognized the ways in which the new forms of mass media were drastically altering both the social and personal lives of their audiences, establishing new modes of perception and new patterns of interplay within the human sensorium.

As previously mentioned, one of the features that unites Lewis and McLuhan is the privilege that both give to space over time. Richard Cavell (2002: 4) is quite correct in noting that 'space is the single most consistent conceptual category within McLuhan's highly eclectic body of work', representing the ratios and proportions between the senses that are engendered by media technologies. Given that these media 
Thomas Sutherland (2018) 'Searching for stillness in the flux of the electric world: Vorticular media theory from Wyndham Lewis to Marshall McLuhan', Explorations in Media Ecology. 17 (1): 7-22.

https://doi.org/10.1386/eme.17.1.7_1

'shape and reshape our perceptions', space for McLuhan (1995: 186) is, in effect, an expression of the way in which a medium 'determines the modes of perception and the matrix of assumptions within which objectives are set'. It is the environment or ecology through which media at any one time in history come to affect us and shape both our thoughts and our behaviour, adjusting the focal point of consciousness. Most famously, McLuhan perceives over the course of the twentieth century a gradual shift (beginning with the radio and telephone, but only really finding its culmination in television) from the visual space associated with print, to a new acoustic or auditory space related to, but not identical with, that of preliterate cultures. This retribalization (one of many problematic metaphors of which he is fond) involves a move away from the static, abstract, and fragmentary space of the former toward a 'magical resonating world of simultaneous relations' (McLuhan 1962: 22).

It is often presumed that McLuhan (1962: 31) was wholeheartedly supportive of this 'electronic interdependence' arising from acoustic space, and the global village that was supposed to arise as a result of it. This, however, would be a quite grave misunderstanding of his project, which evinces less an unqualified enthusiasm for the new media of his time, and more a disinterested desire to comprehend the effects that they had wrought. It is in light of this that we can understand McLuhan's (2003: 17) praise of Lewis for his 'utmost contempt for the Zeitgeist'. Whilst the Futurists - whose 'extroversion of the self and fusion with the activity of the machine' (McLuhan 1951: 90) he sees as wholly consonant with Italian fascism - dived headfirst into the fast-moving currents of technological progress, Lewis was far more cautious in his approach. McLuhan (2011d: 7) admires his 'vortex view of art and civilization' precisely because it refuses to allow art to be caught up in this trendy romanticization of new media, but instead uses the tools of the past (in particular, the rational, contemplative mindset of the literate scholar) in order to highlight the failings of the present. This perspective on media history is central to McLuhan's broader project, which is always trying to seek out those truths that remain invisible to us whilst we are numbed by the anaesthetic effects of a contemporary media space - as Donald Theall (1971: 22) observes, McLuhan 'makes history important by making it the way of understanding the "now", so that '[w]ithout discussion of the Greeks, of the Middle Ages, of the Renaissance, and of the intervening centuries, it would not be possible to see what actually is happening in the current period'.

'[O]ur job in the new electronic age,' McLuhan (1962: 77) declares, is 'to study the action of the new vortex on the body of the older cultures'. We must understand the way in which a new media environment incorporates previous media within itself, transforming its form into content, and in doing so, we might find ourselves able to illuminate those alterations in perception that have come along with such a transition. If there is a specific allure for McLuhan (1997: 21) in the simultaneity of the electric world, it is in that capacity for wisdom (as he describes it), that comes from 'perceiving and stating causes and effects at the same time', forcing us to examine above all else the formal cause of the medium - that is, its effects in totality. It is the artist, it would seem, who is more than anyone else able to provide such an elucidation: 'anti-environments, or counter-environments created by the artist, are indispensable means of becoming aware of the environment, in which we live and of the environments we create for ourselves technically' (McLuhan 1967: 165). It is unsurprising, then, given that he ascribes to art this role of deliberate untimeliness, bringing to light the determinative (and potentially oppressive) features of any one media space, that McLuhan (2011d: 6) would see such value in the Vorticist conception of art, which seeks to 'arrest the flux of existence in order that the mind may be united with that which is permanent in existence'. In Lewis' view, McLuhan (2011d: 10) writes, 'the moment of art is not a moment of time's covenant', but is that which eludes the vicissitudes of temporal movement.

Art is a vortex that 'plunges to the heart of the Present' (Lewis 1914b: 147) - an aesthetic solidification of time momentarily disrupting the entrancing, hypnotic flux of the world around us (and more specifically, the seductive velocities of the industrial society). As Elena Lamberti (2012: 219-220) argues, 
Thomas Sutherland (2018) 'Searching for stillness in the flux of the electric world: Vorticular media theory from Wyndham Lewis to Marshall McLuhan', Explorations in Media Ecology. 17 (1): 7-22.

https://doi.org/10.1386/eme.17.1.7_1

McLuhan conceives of Lewis' vortex not 'as a flux, but as a dynamic, progressive, moving image related to time but also containing a stable point, the spatial element from which its energy spirals originate'. It is not that this vortex freezes time, but that it offers a viewpoint from which one can observe the process of time from outside of itself, distancing oneself from the continual movement within which we usually seem to be trapped, following 'the perception of something which is arrested briefly while progressing' (Lamberti 2012: 220). McLuhan (2011d: 11) is no doubt right when he notes that Lewis' artistic intellectualism, 'seeing the movements of vision as an arrest and detachment of the great mechanism of the world', is strongly Schopenhauerian in character: for Schopenhauer (2010: 417), who despised the German idealists' fixation upon historical becoming, the primary worth of aesthetic beauty, and the pleasure derived from it, 'largely consists in the fact that we have entered into a state of pure contemplation, momentarily suppressing all willing, i.e. all desires and concerns'. Where this approach, however, emphasizes the blissful and meditative state to which such judgement gives rise - making 'the aesthetic moment of stasis memorable as the prime means by which one could, as it were, stop the world and get off (McLuhan and Parker 1968: 22) - Lewis' vortex is instead a concentration of violent energies within a whirling mass that remains in constant tension between stasis and movement.

\section{The politics of time in Lewis and McLuhan}

This appeal to Lewis, and the image of the vortex, is a clear indication of how misguided the stillcommonplace depiction of McLuhan as a dogmatically enthusiastic advocate for the age of electric (and electronic) media really is. In the introduction to the Gutenberg Galaxy, McLuhan (1962: 3) makes it abundantly clear that, in spite of any apparent technological determinism present within his writing, the purpose of his work is not to reveal humanity's powerlessness in the face of the media that it has produced, but to 'elucidate a principal factor in social change which may lead to a genuine increase of human autonomy'. The often breathless zeal he seems to hold in relation to new media technologies manifests not because he views such change as inherently valuable (a teleological conception of media development that is entirely foreign to his theory), but because he remains convinced that within any media environment, we can find the tools to emancipate ourselves from its grip upon our thoughts and perception. Hence why he commends Lewis for aiming 'toward the pole of intelligibility instead of that of feeling' (McLuhan 2011d: 11): in the face of an accelerating pace of technological change, both Lewis and McLuhan hope to foreground those necessary truths that would allow us a certain agency precisely because they are not subject to the fickle variability of these trends. Both Lewis and McLuhan 'consciously embraced the challenge of being intellectuals in a shifting hyper-technological world' (Lamberti 2016: 40 ), but they did so not to merely be passively subjected to these changes, but to take an active role in apprehending and shaping them.

It is not so surprising, then, when McLuhan (2003: 101) declares himself as 'resolutely opposed to all innovation, all change' - a deliberately hyperbolic attenuation of the aforementioned perceived enthusiasm, but an important one nonetheless - for his aim is not to single-mindedly promote the advantages of the electric age, and the acoustic space that he claims to have arisen from it, but to combine them with the capacities of reason (and more specifically, those whetted by the visual space of print: precision, divisibility, isolation, etc.) in order to identify and critique the ever-accelerating chaos of this new media environment. Whereas for Bergson 'the emotions are used as the principal windows of the soul' (McLuhan 2011d: 11), intuition being accorded a primacy over all intellection (which divides the world up into segments capable of being analysed and categorized), in this account it is exactly such an ability to view the world from a viewpoint not beholden to such flux that offers us the possibility of genuine autonomy. Following his famous dictum that the content of one medium is always another medium (such that the latter is transformed into an art-form), McLuhan views Lewis' prescience as lying 
Thomas Sutherland (2018) 'Searching for stillness in the flux of the electric world: Vorticular media theory from Wyndham Lewis to Marshall McLuhan', Explorations in Media Ecology. 17 (1): 7-22.

https://doi.org/10.1386/eme.17.1.7_1

in his ability to take the conventions of print and unwittingly placing them within a formal framework derived from the new electric media, thus revealing the hidden dimensions of a media environment that would otherwise remain invisible. Lewis' art and writing 'anticipated the rear-projection and strong bounding lines of the iconoscope form of the TV image' (McLuhan 1987: 374).

If we wish to hail McLuhan $(1964: 47,224)$ as a prophet of the digital age, it should not be because he predicted the internet (or other such unnecessary hyperbole), but because he foresaw this time in which 'information is the crucial commodity', overwhelming the senses and necessitating the increasing delegation of information production and processing to automated systems of computation, the latest example of 'self-amputation as an immediate relief of strain on the central nervous system'. Neil Postman (1992: 70) once observed that we live in a media environment in which information appears indiscriminately, directed at no one in particular, in enormous volume and at high speeds, and disconnected from theory, meaning, or purpose', and this is truer now than ever. Under such conditions, there is a pressing need to foreground modes of knowledge that bypass or resist this ever-accelerating glut of data.

In a technological epoch governed not by biological rhythms, or even the regularity of the clock, but by the seemingly instantaneous operations of digitally networked media - the point when 'the measure of the world becomes that of the vector of movement' (Virilio 2009: 62) - it is refreshing to rediscover this appeal to the virtues of stasis, of a philosophy that refuses to get caught up in the flows of globalized capitalism. This is a stasis that is not attained through a deliberate slow-down or refusal of this temporality (as we tend to witness in Virilio), however, but instead via an exploitation of the pattern recognition that this temporality enables. 'In an age of accelerated change, the need to perceive the environment becomes urgent. Acceleration also makes such perception of the environment more possible' (McLuhan and Parker 1968: 252-253).

This is not to suggest that the typical critiques of McLuhan - his oracular and prolix prose; his exaggerated and sloganistic declarations, seemingly lacking in appreciably argumentative rigour; his overly broad dualisms - are at all unreasonable. We must always be cautious in the usage of his percepts, ensuring that we are not seduced by the colourful but often insubstantial flamboyance of his writing. But what is often missed in such critiques is the strongly normative nature of his work, his exhortation to heterodox, recusant thought. McLuhan (1995: 213) in many ways seems to imagine himself more an artist than a philosopher, observing that in modernist art and poetry the 'training of perception upon the otherwise unheeded environment became the basis of experimentation', the result being that the artist 'turned his senses and the work of art to the business of probing the environment' - a procedure that also forms the basis of his own writings, making the present alien to itself through the resources of the past. After all, ' $[\mathrm{t}]$ he artist is the man in any field, scientific or humanistic, who grasps the implications of his actions and of new knowledge in his own time' (McLuhan 1964: 72). The media environments within which we live are as invisible to us as the air that we breathe, but through the construction of a counter-environment which draws upon the resources of prior environments without merely expressing a straightforward nostalgia, the artist is capable of, at the very least, illuminating the determinate horizon of a particular media space. '[T] he contemporary artist attempts to chart the psychological chaos created in the heart of man by a mechanistic society' (McLuhan 2011c: 98).

As prescient as they were, surely neither Lewis nor McLuhan could really predict the sheer intensity of socio-technical acceleration that is now imposed upon us. Even art movements themselves, observes Laura Marks (2002: 198), are now subject to incessant cycles of novelty, reification or commercial arrogation, and obsolescence, as a ramification of 'the market-driven anxiety to produce something new'. But both writers' emphasis upon the stillness at the heart of such flux contains genuine subversive value at a time when 'sensation overtakes the logical order' (Virilio 2009: 45), our faith in the surety of any law 
Thomas Sutherland (2018) 'Searching for stillness in the flux of the electric world: Vorticular media theory from Wyndham Lewis to Marshall McLuhan', Explorations in Media Ecology. 17 (1): 7-22.

https://doi.org/10.1386/eme.17.1.7_1

or principle having been shaken by years of epistemic disorientation. It would be misguided to believe that to seek out stability, to desire some respite from this tumult, is inherently conservative or backwardlooking. Such a goal may be idealistic, almost impossibly so, but in its idealism it represents a distinct break from the ideologies of speed, productivity, and efficiency around which post-industrial capitalism is oriented, capturing instead a tension between stasis and flux, being and becoming.

This approach is not in itself foreign to the traditions of aesthetic theory which, writes David Harvey (1989: 205), 'seeks out the rules that allow eternal and immutable truths to be conveyed in the midst of the maelstrom of flux and change'. But such an assertion of artistic autonomy - the right to not be subjected to the imperatives of economic rationalism - combined with a dogged opposition to the overt valorization of dynamism, does mark out a particular place for the Vorticists within the recent history of Western aesthetics. As Fredric Jameson (1979: 3-4) notes, Lewis' unapologetic diagnoses in in Time and Western Man 'had the unfortunate effect of forcing his readership to choose between himself and virtually everything else (Joyce, Pound, Proust, Stein, Picasso, Stravinsky, Bergson, Whitehead, etc.) in the modern canon'. The affect of his work is even more profound today, given the general equation of freedom and motility/mutability that is taken for granted as much by scholars and artists as it is by the ideologues of industry: so often, the usage of philosophers of becoming (viz. Nietzsche, Bergson, Whitehead, Deleuze) within the humanities and social sciences seems to be justified on the basis of a generalized perception of flux, even whilst touting the subversive qualities of the former, effectuating an undecidable blurring of the transcendental and empirical. The notion of art as vortex is unabashedly opposed to such reification of the certitude of becoming.

Unfortunately, however, whilst their end-goals in this respect are sound, neither Lewis nor McLuhan have terribly appealing political visions for those of us working within the framework of a leftist politics. Although Lewis presents Futurism as a kind of fascism avant la lettre, he himself flirted with Nazism (motivated in large part by his virulently anti-communist leanings), and was at various times misogynistic, anti-Semitic, xenophobic, and homophobic, none of which makes his work entirely unsalvageable, but certainly calls into question the degree to which we should imprudently make use of his philosophical precepts.

Likewise, although McLuhan (1964: 72) could not be accused of expressing the type of vitriolic hatred that we see sometimes in Lewis (his chauvinism and orientalism, whilst regrettable, being largely consonant with the norms of the time in which he was writing), his exuberant insistent upon the simultaneously critical and affirmative powers of creative thought is accompanied by a deeply orthodox, Roman Catholic vision of the artist as a prophet whose ability to find order within chaos (and in doing so, the elude the grasp of fate) is derived from an integral awareness that accords with a divine natural law, giving them an almost literally prophetic ability to 'sidestep the bully blow of new technology'. As Florian Sprenger argues:

[f]or McLuhan, as for his disciples Eric McLuhan, Derrick de Kerckhove and Paul Virilio, media theory in the end is a Catholic project, and only a Catholic can truly understand what media theory is about. Only a Catholic can join the heaven of media theory (2014: 44).

Although there is no especially compelling reason for those of us who do not share these quite specific theological commitments to reject McLuhan's work wholesale (in the same way that so many find value in Lewis' artwork and writings in spite of his often unpleasant political views), it is important that we consider the extent to which his challenge to the hegemony of time-philosophy can be maintained outside of this context. 
Final version published as:

Thomas Sutherland (2018) 'Searching for stillness in the flux of the electric world: Vorticular media theory from Wyndham Lewis to Marshall McLuhan', Explorations in Media Ecology. 17 (1): 7-22.

https://doi.org/10.1386/eme.17.1.7_1

\section{The agonies of media theory}

In a letter written whilst he was still a student, McLuhan (1987: 74) declares 'there is a true and eternal pattern for human life which the "progress" mongers wot not of, proposing art as an attempt to realize this pattern that emanates directly from God. And in fact, as much as McLuhan (1999: 7) is feted for his forward-looking and prescient ruminations on new media, underpinning his outlook on the world is a curious scholastic mediaevalism, premised on the notion that in the Middle Ages 'certain timeless principles were then understood which have since been foolishly forgotten'. Thus, when he presents the vortex-form of modernist art as a means of retrieving the eternal truths that persist amongst the turmoil of everyday life, he is referring to quite specific truths, rather different from those proffered by Lewis (which are largely centred upon the power of the individual intellect and the autonomous artwork to overcome the banality of the quotidian), in spite of his admiration for the latter's methods. McLuhan, in one of his more candid moments, declares:

I am a Thomist for whom the sensory order resonates with the divine Logos. I don't think concepts have any relevance in religion. Analogy is not concept. It is community. It is resonance. It is inclusive. It is the cognitive process itself. That is the analogy of the divine Logos (1987: 368369).

Whereas the mediaeval artist worked in a milieu wherein the unity of all things under the aegis of God was already given, their work infused with the divine patterns of this logos and hence inherently reflective of the goodness of God (an analogical relation), the modern artist must create this order anew.

It is the artist who is able to effectuate such a creation (or restoration) because the inherently participatory nature of the modern artwork (and the artist's necessary solicitude for their audience) demands precisely the kind of sensory interplay that was long-neglected within print culture. All 'art must always start with the effect', McLuhan (2011b: 18) declares, which is 'another way of saying that art must start with formal cause, and with concern with the audience'. Formal cause (in an idiosyncratic mutation of scholastic terminology) is here understood not as a kind of static, pre-determined template; rather, it is the result of the affective potentialities of the audience, designating the indistinguishability of a medium from its total effect upon said audience, outside the linear temporality of efficient causality. This formal cause, then, is exactly the vortex-form that McLuhan celebrates, producing intellectually purified images of the entelechy of nature' (McLuhan 2011d: 14), capturing a stillness within flux that is only possible on the basis of a reciprocal interchange between artist and audience, and an accordant sensory awareness that taps into this spirit of mutual exchange. It was the artists who 'took up the cause of formal causality [...] after the philosophers had abandoned it', McLuhan (1999: 36) asserts, for whilst the philosophers' visual bias led to a mechanistic privileging of efficient cause (which would in turn lead to the uncritical celebration of 'progress' by the Futurists), it was the artists' ability to manipulate and divert the ratios between the senses that conversely allowed them to create works that undercut this linear temporality.

The work of Lewis and other such avant-garde modernists acted 'to cleanse the stream of speech, update sensibility, and train perception', the latter of which in particular 'McLuhan considered to be the necessary propaedeutic for the re-invigoration of morality and prudence given that both are necessary virtues of the free citizen and ruler in civil society' (Chrystall 2008: 9-10). The question of human agency, which McLuhan is so often seen as wholeheartedly ignoring, is in fact deeply rooted within his media theory. 'Determinism is the result of the behaviour of those who are determined to ignore what is happening around them' (McLuhan 1987: 334). Both art and scholarship, then, play a crucial role in illuminating the media environment that surrounds us at any one time, and this is exactly the approach that McLuhan takes in his role as philosopher and theorist: using it as a form of art, creating vortexes that 
Thomas Sutherland (2018) 'Searching for stillness in the flux of the electric world: Vorticular media theory from Wyndham Lewis to Marshall McLuhan', Explorations in Media Ecology. 17 (1): 7-22.

https://doi.org/10.1386/eme.17.1.7_1

isolate and identify the particular sensory and somatic focal points of the media environment by which he is surrounded. This is a decidedly normative (and even moralistic) project, understanding the role of the theorist not as to take a particular point of view in regard to a contingent state of affairs, but to bring to light through aesthetic means the usually-invisible features of that environment so that we might carve out a niche of autonomy within it. Hence the often initially opaque style of his writings which constitute 'avant-garde experiments in a form which intends to transcend the limits of the printed page and to involve the reader in a new, dynamic vortex of situations and speculations', as Lamberti (2012: 15) describes, and 'the simultaneous experience of multiple phenomena coalescing into the centre of a great power' (2016: 29), as Gregory Betts likewise puts it.

The convergence of McLuhan and Lewis outlined in this article is surely more relevant than ever, given how fashionable the ontologies of Bergson and Whitehead are within contemporary theory. In fact, it would surely not be unreasonable to suggest that the time-philosophy toward which so much of Lewis' opprobrium is directed has been largely normalized today, the priority of becoming over being not only treated as a veritable truth (bolstered on one side by quantum physics, and other forms of science that have challenged the Newtonian image of the world, and on the other side by a thoroughgoing antiessentialism both in and out of the academy), but as an ethical goal (a categorical imperative) toward which we must strive. The emphasis upon seeking out stillness in the flux of modern society provides an important reminder that the theorization of media does not need to remain wholly enslaved to the furious tempo of technological change. Vorticism, observes Wees (1972: 40, 90) was borne of the intuition that 'avant-garde movements must catch the public eye quickly and effectively, because they are essentially as ephemeral as today's headlines' - an approach that McLuhan also adopts, embracing the tone and aesthetics of consumerist marketing and public relations - but at the same time it opposes itself to the 'violent sort of Bergsonian flux' advocated by the Futurists. Media theory, in this context, must remain relevant and pertinent, always immanent to the media environment by which it is moulded, but it must do so precisely in order to identify that which transcends this state of affairs. '[S] uch a grotesque extension of reality,' writes Lamberti (2012: 222), 'arrests it, halts its intensity, and makes us readers "see” inside the flux because, for a few moments, space wins over time'.

'The universal human condition today in a period of rapid innovation is necessarily that of alienation' (McLuhan and Watson 1970: 8-9), but this is not necessarily a bad thing. Alienation can be understood as a mode of distancing, leading to a critical, ironic, or dispassionate viewpoint. This is the type of tranquil contemplation that Schopenhauer (2010: 209) seeks out in his aesthetic theory, maintaining a pure cognitive subjectivity that in turn discerns those universal objects that are 'the permanent, essential forms of the world and all its appearances', momentarily unfazed by the ceaseless fluctuation and movement of quotidian existence. 'Schopenhauer made the aesthetic moment of stasis memorable as the prime means by which one could, as it were, stop the world and get off (McLuhan and Parker 1968: 22), transforming the romantic figure of the genius into the artist who is capable of freeing themselves, however fleetingly, from the unsatisfying desires and drives of the will to life. And whilst many of us might express incredulity regarding the verity of such eternal truths (a scepticism that McLuhan himself, of course, did not possess), there is nonetheless a principle here worthy of consideration. As Wendy Hui Kyong Chun (2016: 15, 171) has expounded, in the 'enduring ephemerality' of new media - a media environment in which the demand for new media forms is as insistent as that for new content - 'what matters most is what and how things linger'. Rather than getting caught up in the maelstrom, we might seek to rise above it, not so that we might wholly nullify it; but to rather identify those elements that are not entirely subsumed within it.

This appeal to transcendence is unfashionable today, so often are we expected to celebrate the endlessly overabundant becoming of an ontological immanence absent of all finitude. But there is a pragmatic importance to such an effort, even once we have jettisoned McLuhan's theological baggage. Lewis' 
Thomas Sutherland (2018) 'Searching for stillness in the flux of the electric world: Vorticular media theory from Wyndham Lewis to Marshall McLuhan', Explorations in Media Ecology. 17 (1): 7-22.

https://doi.org/10.1386/eme.17.1.7_1

spatially-oriented philosophy 'offers McLuhan a conceptual form of writing which is designed, not as a flow, but as mosaic, that is, as a juxtaposition of pauses or intervals in turn blasting the numbing acceptance of actuality' (Lamberti 2012: 223). The vortex is a mode of abstractive disruption, retrieving into the present those truths (so to speak) that would otherwise be drowned in the fast-moving stream of experience. Against the desire to blur the lines between human and machine, seeing in the violent and productive/destructive power of industry the facility to transcend the slow, messy materiality of the body, the vorticular approach that McLuhan (1987: 222) attempts to revive instead 'tries to discern the human shape once more in a vast technological landscape'. The Vorticists had no desire to embrace abstraction entirely, there always remained a representational element to their output, but they utilized abstraction in order to capture that which would otherwise be lost in the thrilling danger of the industrial experience - as Lewis (1914a: 134) himself argues, '[t]he finest Art is not pure Abstraction, nor is it unorganised life'.

Although one cannot do justice to this notion within the confines of a single article, I wish to conclude by suggesting that in order to remain viable as a research discipline (barring dramatic shifts in hegemonic socio-technical logics), media theory must find ways of extracting itself from the categorical imperative of perpetual change and development that privileges the technological sublimity (Nye 1994) of new media forms without adequately considering their potential effects. It must try to counteract the threat of our losing 'the proclivity to contemplate the proper ends of innovation' (Rose 2013: 67).

Geert Lovink (2011:7) is absolutely correct when he opines that the problem with media theory is that "the object of study is in a permanent state of flux and will disappear shortly', such that it will always be 'condemned to history writing'. Instead of treating this as a sign of media theory's inherent defectiveness, its inability to maintain the pace necessary for scholarship in the twenty first century, perhaps we should instead embrace this lag between theory and phenomenon, accentuating 'the technique of the suspended judgment, the great discovery of the twentieth century in art and physics alike' (McLuhan 1962: 278). Such latency, rather than marking the end of critical theory as meaningful tool for understanding the world around us, might on the contrary be conceived of as the exact means by which we regain our critical faculties in the face an overwhelmingly vast and temporally inapprehensible technological and ideological apparatus. Humanity 'was not designed to live at the speed of light' (McLuhan and Powers 1989: 97).

\section{Bibliography:}

Bergson, Henri (1946), The Creative Mind, translated by M. L. Andison. New York: The Philosophical Library.

Betts, Gregory (2016), 'The New Canadian Vortex: Marshall McLuhan and the Avant-Garde Function of Counter-Environments', pp. 18-37 in Counterblasting Canada: Marshall Mcluhan, Wyndham Lewis, Wilfred Watson, and Sheila Watson, edited by G. Betts, P. Hjartarson, and K. Smitka. Edmonton: The University of Alberta Press.

Cavell, Richard (2002), McLuhan in Space: A Cultural Geography. Toronto: University of Toronto Press.

Chrystall Andrew (2008), 'The New American Vortex: Explorations of McLuhan'. Ph.D. thesis, Massey University, New Zealand.

Chun, Wendy Hui Kyong (2016), Updating to Remain the Same: Habitual New Media. Cambridge, MA: The MIT Press. 
Thomas Sutherland (2018) 'Searching for stillness in the flux of the electric world: Vorticular media theory from Wyndham Lewis to Marshall McLuhan', Explorations in Media Ecology. 17 (1): 7-22.

https://doi.org/10.1386/eme.17.1.7_1

Harvey, David (1989), The Condition of Postmodernity: An Enquiry into the Origins of Cultural Change. Cambridge, MA and Oxford: Blackwell.

Hulme, T.E. (1924), Speculations: Essays on Humanism and the Philosophy of Art. London: Routledge.

Jameson, Fredric (1979), Fables of Aggression: Wyndham Lewis, the Modernist as Fascist. Berkeley and Los Angeles, CA: University of California Press.

Lamberti, Elena (2012), Marshall McLuhan's Mosaic: Probing the Literary Origins of Media Studies. Toronto: University of Toronto Press.

Lamberti, Elena (2016), 'Watson, McLuhan (\& Lewis): Conscious (Modernist) Solitudes, Challenging Canadians', pp. 38-57 in Counterblasting Canada: Marshall Mcluhan, Wyndham Lewis, Wilfred Watson, and Sheila Watson, edited by G. Betts, P. Hjartarson, and K. Smitka. Edmonton: The University of Alberta Press.

Lewis, Wyndham (1914a), 'Futurism, Magic and Life', Blast. 1: 132-135.

Lewis, Wyndham (1914b), 'Our Vortex’, Blast. 1: 147-149.

Lewis, Wyndham (1957), Time and Western Man. Boston: Beacon Hill.

Lovink, Geert (2011), Networks Without a Cause: A Critique of Social Media. Cambridge and Malden, MA: Polity.

Mangold, Jana (2014), 'Metaphorical Effects: McLuhan's Media', pp. 15-20 in McLuhan's Global Village Today: Transatlantic Perspectives, edited by C. Birkle, A. Krewani, and M. Kuester. London and Brookfield, VT: Pickering \& Chatto.

Marinetti, Filippo Tommaso (2006), Critical Writings, edited by G. Berghaus, translated by D. Thompson. New York: Farrar, Straus, and Giroux.

Marks, Laura (2002), Touch: Sensuous Theory and Multisensory Media. Minneapolis, MN: University of Minnesota Press.

McLuhan, Marshall (1951), The Mechanical Bride: Folklore of Industrial Man. New York: The Vanguard Press.

McLuhan, Marshall (1962), The Gutenberg Galaxy: The Making of Typographic Man. Toronto: University of Toronto Press.

McLuhan, Marshall (1964), Understanding Media: The Extensions of Man. London and New York: Routledge. 
Thomas Sutherland (2018) 'Searching for stillness in the flux of the electric world: Vorticular media theory from Wyndham Lewis to Marshall McLuhan', Explorations in Media Ecology. 17 (1): 7-22.

https://doi.org/10.1386/eme.17.1.7_1

McLuhan, Marshall (1967), 'The Invisible Environment: The Future of an Erosion', Perspecta. 11: 161167.

McLuhan, Marshall (1987) Letters of Marshall McLuhan, edited by M. Molinaro, C. McLuhan, and W. Toye. Oxford: Oxford University Press.

McLuhan, Marshall (1995), Essential McLuhan, edited by E. McLuhan and F. Zingrone. London: Routledge.

McLuhan, Marshall (1997), Media Research: Technology, Art, Communication, edited by M.A. Moos. Amsterdam: Overseas Publishers Association.

McLuhan, Marshall (1999), The Medium and the Light: Reflections on Religion, edited by E. McLuhan and J. Szklarek. Toronto and New York: Stoddart.

McLuhan, Marshall (2003), Understanding Me: Lectures and Interviews, edited by S. McLuhan and D. Staines. Toronto: McClelland \& Stewart.

McLuhan, Marshall (2011a), Counterblast. Berlin: transmediale.

McLuhan, Marshall (2011b), 'Formal Causality in Chesterton', pp. 15-19 in Theories of Communication. New York: Peter Lang.

McLuhan, Marshall (2011c), 'Introduction: Paradox in Chesterton', pp. 95-101 in Theories of Communication. New York: Peter Lang.

McLuhan, Marshall (2011d), 'Wyndham Lewis: His Theory of Art and Communication', pp. 5-14 in Theories of Communication. New York: Peter Lang.

McLuhan, Marshall and Barrington Nevitt (1972), Take Today: The Executive as Dropout. New York: Harcourt Brace Jovanovich.

McLuhan, Marshall, and Harley Parker (1968), Through the Vanishing Point: Space in Poetry and Painting. New York: Harper \& Row.

McLuhan, Marshall and Bruce Powers (1989), The Global Village: Transformations in World Life and Media in the 21st Century. Oxford: Oxford University Press.

McLuhan, Marshall and Wilfred Watson (1970), From Cliché to Archetype. New York: The Viking Press.

Nye, David E. (1994), American Technological Sublime. Cambridge, MA: The MIT Press.

Postman, Neil (1992) Technopoly: The Surrender of Culture to Technology. New York: Vintage Books.

Rose, Ellen (2013), On Reflection: An Essay on Technology, Education, and the Status of Thought in the Twenty-First Century. Toronto: Canadian Scholars' Press. 
Thomas Sutherland (2018) 'Searching for stillness in the flux of the electric world: Vorticular media theory from Wyndham Lewis to Marshall McLuhan', Explorations in Media Ecology. 17 (1): 7-22.

https://doi.org/10.1386/eme.17.1.7_1

Schopenhauer, Arthur (2010), The World as Will and Representation, Volume 1, translated by J. Norman, A. Welchman, and C. Janaway. Cambridge: Cambridge University Press.

Sprenger, Florian (2014), 'Global Immediacy', pp. 31-46 in McLuhan's Global Village Today: Transatlantic Perspectives, edited by C. Birkle, A. Krewani, and M. Kuester. London and Brookfield, VT: Pickering \& Chatto.

Theall, Donald (1971), The Medium is the Rear View Mirror: Understanding McLuhan. Montreal: McGill-Queen's University Press.

Virilio, Paul (2006), Speed and Politics, translated by M. Polizzotti. Los Angeles, CA: Semiotext(e).

Virilio, Paul (2009), The Aesthetics of Disappearance, translated by P. Beitchman. Los Angeles: Semiotext(e).

Watson, Sheila (2003), Wyndham Lewis and Expressionism. Waterloo: MLR Editions Canada.

Wees, William C. (1972), Vorticism and the English Avant-Garde. Toronto: University of Toronto Press.

Whitehead, A.N. (1925), Science and the Modern World. New York: The New American Library. 